\title{
ValpoScholar
}

Valparaiso University Law Review

Volume 32

Number 3 Summer 1998

pp.793-831

\section{Summer 1998}

\section{Protecting Property with Puts}

Ian Ayres

Follow this and additional works at: https://scholar.valpo.edu/vulr

Part of the Law Commons

\section{Recommended Citation}

Ian Ayres, Protecting Property with Puts, 32 Val. U. L. Rev. 793 (1998).

Available at: https://scholar.valpo.edu/vulr/vol32/iss3/1

This Monsanto Lecture is brought to you for free and open access by the Valparaiso University Law School at

ValpoScholar. It has been accepted for inclusion in

Valparaiso University Law Review by an authorized administrator of ValpoScholar. For more information, please contact a ValpoScholar staff member at scholar@valpo.edu. 


\title{
VALPARAISO UNIVERSITY LAW REVIEW
}

\begin{tabular}{lll}
\hline \hline VOLUME 32 & SUMMER 1998 & NUMBER 3 \\
\hline \hline
\end{tabular}

\section{Monsanto Lecture}

\section{PROTECTING PROPERTY WITH PUTS}

\author{
IAN AYRES
}

\section{TABLE OF CONTENTS}

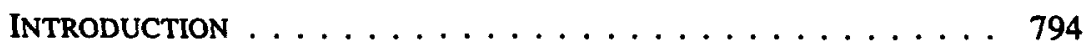

I. The Normative CASE for PUts $\ldots \ldots \ldots \ldots \ldots \ldots$. . . 801

A. Distributional Differences . . . . . . . . . . . . . . 804

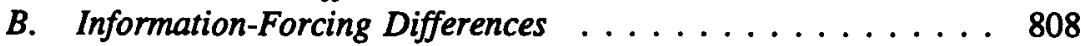

C. Bid-Ask Differences . . . . . . . . . . . . . . . . . 809

II. The Descriptive Prevalence of Puts $\ldots \ldots \ldots \ldots \ldots$

III. Putting UP WITH Nuisance $\ldots \ldots \ldots \ldots \ldots \ldots \ldots$

A. The Numerosity Problem . . . . . . . . . . . . . . . 819

B. Facilitating v. Deterring the Initial Taking . . . . . . . 823

C. Trespass, Nuisance, and the Costs

of Determining Property Rights . . . . . . . . . . . 828

ConCLusion $\ldots \ldots \ldots \ldots \ldots \ldots \ldots \ldots \ldots \ldots$

- Townsend Professor, Yale Law School. ayres@mail.law.yale.edu. Jack Balkin, Robert Ellickson, Richard Epstein, Dan Farber, Paul Goldbart, Russell Korobkin, James Krier, Paul Mahoney, Jeff Rachlinski, Carol Rose, Stewart Schwab, Peter Siegelman, and Laura Underkuffler provided helpful comments. This lecture is dedicated to Laura Gaston Dooley-coauthor, yenta, and friend-in memory of our many evenings eating raita and singing "Hallelujah, I'm a Bum." The 1998 Monsanto Lecture in Tort Reform and Jurisprudence was presented March 27, 1998, at Valparaiso University School of Law. 


\section{INTRODUCTION}

One View of the Cathedral is famous in part because Guido Calabresi and Douglas Melamed noticed a missing category in the ways that courts resolved nuisance disputes. ${ }^{1}$ Consider the classic-if somewhat idealized-nuisance dispute between a single "Polluter" and a single "Resident" who is discomforted by the pollution. Courts had traditionally chosen among three different outcomes:

Rule 1: a court might issue an injunction against a Polluter;

Rule 2: a court might find a nuisance but permit pollution to continue if the Polluter chose to pay damages; or

Rule 3: a court might find the pollution not to be a nuisance and permit the Polluter to continue without paying damages.

But Calabresi and Melamed, by appreciating the difference between liability and property rules, saw that these three approaches naturally fit into a two-by-two box.

Table 1. Calabresi and Melamed's Two-by-Two Box with the Missing Category

\begin{tabular}{|c|c|c|c|}
\cline { 3 - 4 } \multicolumn{2}{c|}{} & \multicolumn{2}{c|}{$\begin{array}{c}\text { Method of } \\
\text { Protection }\end{array}$} \\
\cline { 2 - 4 } $\begin{array}{c}\text { Initial } \\
\text { Entitlement }\end{array}$ & $\begin{array}{c}\text { Property } \\
\text { Rule }\end{array}$ & $\begin{array}{c}\text { Liability } \\
\text { Rule }\end{array}$ \\
\cline { 2 - 4 } & Resident & Rule 1 & Rule 2 \\
\hline
\end{tabular}

The problem with the traditional three-way approach was that one of the boxes was empty. Calabresi and Melamed's theory suggested a fourth approach:

1. Guido Calabresi \& A. Douglas Melamed, Property Rules, Liability Rules, and Inalienability: One View of the Cathedral, 85 HARV. L. REV. 1089 (1972). 
Rule 4: a court might permit a Polluter to continue unless the Resident chose to pay the Polluter damages in order to enjoin further pollution.

As fate would have it, the fourth box would not stay empty for long. In Spur Industries v. Del Webb, Justice James D. Cameron of the Arizona Supreme Court-in what has probably become the most cited "coming to the nuisance" decision-found that pollution could be enjoined but that the a developer representing residents had to "indemnify [the Polluter] for a reasonable amount of the cost of moving or shutting down." Just as Einstein's reputation grew when he was able to predict that gravity could bend light just before a natural experiment dramatically proved his claim, ${ }^{3}$ Calabresi and Melamed's good fortune in identifying a vacuum that was almost simultaneously filled helped solidify their article's well deserved fame.

This narrative is well known by the vast majority of tort (and property) professors. ${ }^{4}$ However, the legal academy seems to be much less aware of an analogous phenomenon that has been developing over the last five years. Starting in 1993 with Madeline Morris's article, The Structure of Entitlements, ${ }^{5}$ a group of about a half dozen scholars have started to see "liability rule" protection as a type of call option. ${ }^{6}$ Just as the property/liability rule distinction

2. Spur Indus., Inc. v. Del E. Webb Dev. Co., 494 P.2d 700, 708 (Ariz. 1972) (Cameron, V.C.J.). The court's unconditional order seems different than the definition of Rule 4 in the text which gives the Resident the choice of whether (a) to pay to stop further pollution or (b) not to pay and to allow the Polluter to continue polluting. To harmonize the case with the definition, it is necessary to speculate what would have happened if Del Webb had petitioned the court to void its order enjoining the pollution as well as its order that Del Webb indemnify Spur. If we believe that the court would have in effect allowed Del Webb to withdraw its initial complaint, it would have in effect been giving Del Webb the Rule 4 choice-that is, the choice of paying to stop pollution or not paying and allowing the pollution to continue. Or at a minimum, future developers will realize that suing in this jurisdiction may be choosing to pay for an injunction.

3. GeORge Gamow, ONE TWO THREe . . . INFINITY 108 (1961); STEPHEN W. HaWking, A BRIEF History OF Time: From THE Big Bang to BlaCK HOLES 10 (1988).

4. Indeed, it is possible to find probably a dozen other articles with a similar narrative. See, e.g., Robert C. Ellickson, Alternatives to Zoning: Covenants, Nuisance Rules, and Fines as Land Use Controls, 40 U. CHI. L. REv. 681 (1973); James E. Krier \& Stewart J. Schwab, Property Rules and Liability Rules: The Cathedral in Another Light, 70 N.Y.U. L. REv. 440, 442 (1995).

5. Madeline Morris, The Structure of Entitlements, 78 CORNELL L. REV. 822, 854-56 (1993).

6. Ian Ayres \& J.M. Balkin, Legal Entitlements as Auctions: Property Rules, Liability Rules, and Beyond, 106 YALE L.J. 703, 729-33 (1996); Ian Ayres \& Eric Talley, Solomonic Bargaining: Dividing a Legal Entitlement to Facilitate Coasean Trade, 104 YALE L.J. 1027 (1995); Richard Epstein, A Clear View of the Cathedral: The Dominance of Property Rules, 106 YALE L.J. 2091 (1997); Krier \& Schwab, supra note 4, at 471; Saul Levmore, Unifying Remedies: Property Rules, Liability Rules, and Startling Rules, 106 YALE L.J. 2149 (1997); Carol M. Rose, The Shadow of the Cathedral, 106 YALE L.J. 2175 (1997). Because the entitlements at issue in nuisance disputes are usually not susceptible to trading in thick markets, many results of financial economics-such 
helped Calabresi and Melamed discover the missing Rule 4, the call option recategorization naturally leads to consideration of not one, but two additional missing categories.

A call option is an option to buy. The option holder can force a sale at the exercise price even if the seller does not want to sell. Rules 2 and 4 have just these "call" qualities. Under Rule 2, the Polluter has a call option-the choice to pay damages-the choice, in effect, to buy the Resident's right to clean air and, therefore, to be able to continue polluting. The Resident begins with the initial entitlement (to stop pollution), but the Polluter can force the Resident to sell this right for a judicially determined amount. Rule 4 reverses the identity of the Polluter and Resident. Under Rule 4, the Polluter has the initial entitlement, and the Resident has the call option. The Resident can force the Polluter to sell this right to pollute for a judicially determined amount.

Once a liability rule was conceived of as giving someone a call option, it became almost inevitable that scholars would wonder whether "put option" rules might not also be possible. A put option is an option to sell. While call options give the option holder the choice of whether to pay a non-negotiated amount (the exercise price), put options give the option holder the choice of whether to be paid a non-negotiated amount. Call options when exercised give rise to "forced sales"; put options give rise to "forced purchases."

Rule 2 gives the choice of whether to pay to the Polluter; Rule 4 gives the choice of whether to pay to the Resident. Scholars thinking about the classic Rule 2 and Rule 4 cases-Boomer ${ }^{7}$ and Spur -have often only focused on the difference between who pays (the Polluter or the Resident), but a second dimension exists of who chooses to force the payment. Rules 2 and 4 concern a choice to pay, while the put options that are the focus of this Article concern the choice to be paid.

Applied to nuisance disputes, the possibility of put options suggest two additional rules. Each rule gives the initial entitlement holder a put option-the option to force a non-consensual purchase on the other side:

as the Black-Scholes option pricing formula-which rely on a commonly shared value for the underlying asset at any particular moment in time do not apply. RICHARD A. BREALEY \& STEWART C. MYERS, PRINCIPLES OF CORPORATE FINANCE 476-80 (1996). In private correspondence, Paul Mahoney has proven that several of the rules described in this paper would provide equal payoffs if the parties contracted for option rights in thick markets. Correspondence from Paul G. Mahoney, Professor of Law University of Virginia School of Law, to Ian Ayres (Apr. 29, 1998) (on file with author).

7. See Boomer v. Atlantic Cement Co., 257 N.E.2d 870, 875 (N.Y. 1970).

8. See Spur Indus., Inc. v. Del E. Webb Dev. Co., 494 P.2d 700, 708 (Ariz. 1972) (Cameron, V.C.J.). 
Rule 5: a court might allow a Polluter to continue polluting, but also give the Polluter the choice to stop polluting and to receive damages from the Resident; and

Rule 6: a court might allow a Resident to enjoin pollution, but also give the Resident the option of waiving his injunctive rights in return for damages from the Polluter.

Table 1 can be expanded as shown in Table 2 to help flesh out the underlying structure of the six rules.

Table 2. Incorporating the Possibility of "Put Options" Rules

\begin{tabular}{|c|c|c|c|c|}
\hline & & \multicolumn{3}{|c|}{ Method of Protection } \\
\hline & & Property Rule & $\begin{array}{c}\text { Liability Rule } \\
\text { (Initial Enititement } \\
\text { Held Subject To } \\
\text { Other Side's Call } \\
\text { Option to Pay) }\end{array}$ & $\begin{array}{l}\text { "Put Option" or } \\
\text { "Fored Purchase". } \\
\text { Rule } \\
\text { (Initial Entitement } \\
\text { Holder Allo Has Prut } \\
\text { Oppion To Be Paid) }\end{array}$ \\
\hline \multirow{2}{*}{$\begin{array}{c}\text { Initial } \\
\text { Entitlement } \\
\text { Held By }\end{array}$} & Resident & Rule 1 & Rule 2 & Rule 6 \\
\hline & Polluter & Rule 3 & Rule 4 & Rule 5 \\
\hline
\end{tabular}

The rules in the upper and lower rows are identical except for the identity of the initial entitlement holder. This can easily be seen by comparing Rules 1 and 3 . Each gives a property-rule protected entitlement to the Resident or Polluter respectively. But it also applies to Rules 5 and 6 which are similar except that under Rule 5 the Polluter has the initial entitlement and a put option while under Rule 6 the Resident has the initial entitlement and a put option. ${ }^{9}$ The rules in the three columns of the table differ only as to which party has the option to force a non-consensual transfer of the initial entitlement: under a property rule, neither side has an option to force a transfer; under a liability rule, the nonentitlement holder has an option to force the entitlement holder to sell; and

9. It would have been more natural to give the top row consecutive numbers. This table, however, like a gothic cathedral has been added onto over time. I have chosen to label the polluter put as Rule 5 merely to conform to Saul Levmore's prior usage. See Levmore, supra note 6, at 2163. 
under what I am calling a "put option" or "forced purchase" rule, the entitlement holder has the option to force the non-entitlement holder to purchase. ${ }^{10}$

The option recharacterization not only allows us to see the possibility of two more rules, but also clarifies that liability rules (and "put option" rules) are not merely different ways of protecting an entitlement. They can also be thought of as different ways of dividing the parties' claims to the entitlement. As Carol Rose recently wrote:

[Under a property rule regime], the entitlement holder has the whole meatball, so to speak, and the other party has nothing-one has property, the other has zip. Under either of the two liability rules, on the other hand, the meatball gets split: The factory has an option to pollute (or once exercised, an easement), while the homeowner has a property right subject to an option (or easement). For the sake of simplicity, I will refer to this kind of right as a PRSTO (or PRSTE), for "property right subject to an option (or easement)."

Under this view, options merely divide the claims to an entitlement in a different way than say a physical or temporal partition. ${ }^{12}$ The ways that our six rules divide the parties' claims to an entitlement are depicted in Table 3.

Table 3. Possible "Derivative" Divisions of an Entitlement

\begin{tabular}{||c|c|c|}
\hline & \multicolumn{2}{|c|}{ How Different Rules Divide Parties' Claims to an Asset } \\
\hline & Resident's Claim & Polluter's Claim \\
\hline Rule 1 & Asset & 0 \\
\hline Rule 2 & Asset - Call & Call \\
\hline Rule 3 & 0 & Asset \\
\hline Rule 4 & Call & Asset - Call \\
\hline Rule 5 & - Put & Asset + Put \\
\hline Rule 6 & Asset + Put & - Put \\
\hline
\end{tabular}

10. Another column might be added to Table 2 , in which either party could force a nonconsensual transfer. This regime would be equivalent to giving the initial entitlement holder a put option that is simultaneously subject to a call. See Morris, supra note 5, at 856 (discussing this possibility).

11. Rose, supra note 6, at 2178-79.

12. See generally Ayres \& Talley, supra note 6 (discussing dimensions that an entitlement might be divided into, including put and call divisions). 
Table 3 shows how the finite claims to an entitlement are divided by the six rules. Each of the rules maintains conservation of matter, ${ }^{13}$ in that the sum of the Polluter's and Resident's assets and liabilities under each rule nets out to "Asset." As Rose noted, a property rule (such as Rules 1 and 3) gives one party everything and the other person "zip." But, other divisions are possible. Rose saw that having a "PRSTO" is the same as owning the asset subject to a liability (depicted by the "- Call") in that one might be forced to sell against one's will (for a price less than the asset's true value). ${ }^{14}$

Table 3 highlights the radical nature of the "put option" rules. In distributional terms, Rules 5 and 6 go beyond the whole meatball/zip division of traditional property rules. It is possible to have less than zero. The "put option" rules give the initial entitlement holder everything that she would have under a property rule plus a put option. This necessarily implies that the nonentitlement holder has a liability (denoted by "- Put")-i.e., she might be forced to purchase against her will (for a price that is more than her true value).$^{15}$

Possibly because of this seemingly extreme distributional result, ${ }^{16}$ the legal academy has largely rejected "put option" rules as an impractical legal remedy. Richard Epstein, for example, has recently argued: “[L]iability rules, when used, always take the direction of a 'call' . . . . Puts, therefore, are never imposed as a matter of law on strangers but are the outgrowth of consensual

13. Hohfeld long ago showed that rights are relational. See Wesley Newcomb Hohfeld, Fundamental Legal Conceptions as Applied in Judicial Reasoning, 26 YALE L.J. 710 (1917); Wesley Newcomb Hohfeld, Some Fundamental Legal Conceptions as Applied in Judicial Reasoning, 23 YALE L.J. 16 (1913). My right (or asset) can be seen as an obligation (or liability) on someone else's part. The Table's summing to zero captures the Hohfeldian requirement.

14. Seeing liability rules as "derivative" divisions that partition the claims to an entitlement into two parts makes explicit the idea that changing the types of "protection" actually changes the content of the rule. See Jules L. Coleman \& Jody Kraus, Rethinking the Theory of Legal Rights, 95 YALE L.J. $1335,1338-39$ (1986). Seeing liability rules as merely asset divisions also calls into question Richard Epstein's claim for the dominance of "property rules." Because both the PRSTO and the call option are themselves protected by property rules (see Ayres \& Balkin, supra note 6, at 707), his claim must not just be a claim about how entitlements should be protected but a claim about what bundle of strongly protected claims must be bundled together (unpartitioned).

15. While being forced to purchase non-consensually is termed a liability, being subject to the entitlement holder's call does not necessarily mean that the non-entitlement holder will be made worse off in expected utility terms. If the non-entitlement holder would be willing to pay $\$ 80$ for the entitlement and is "forced" to buy it for $\$ 50$, she will be glad the other side exercised its put option. Two articles have shown that optimally structured "put option" regimes need not erode the non-entitlement's expected payoff compared with a simple property rule regime where the nonentitlement holder begins with "zip." Ayres \& Talley, supra note 6, at 1063; Ayres \& Balkin, supra note 6, at 731 . See infra at 16 (discussing how put liability may not, however, lower expected payoff).

16. See Krier \& Schwab, supra note 4, at 472-73; Levmore, supra note 6, at 2163; Morris, supra note 5 , at $855-56$. 
transactions over organized markets." 17 For Epstein, "put option" rules are a missing category, but as a normative matter Epstein believes this to be a happy state of affairs. The legal academy treats the put possibility as an exotic curioso. No one believes that we will be Spurred into seeing its relevance.

The dual thesis of this Article is that put options are a traditional part of the common law and that they should remain so. Contrary to accepted wisdom, the common law does use "put options"-the right to force a non-consensual purchase-as a mechanism for protecting entitlements: (1) if Calabresi steals Melamed's watch, Melamed has the option of suing to recover the watch (replevin) or suing to receive the watch's value (trover); (2) if Calabresi is a holdover tenant in Melamed's apartment, Melamed has the option of suing to enjoin Calabresi's continuing trespass or (at least in some jurisdictions) suing to force Calabresi to rent for up to an entire additional year; and (3) if Calabresi builds an encroaching wall on Melamed's land, Melamed has the option of suing to force Calabresi to remove the wall or suing to force Calabresi to permanently buy the encroached land. In each of these examples, after Calabresi takes Melamed's entitlement, the common law gives Melamed a put option-the option to choose court-determined damages (for permanently ceding the entitlement to the defendant) or injunctive relief (to require the entitlement). Surprisingly, however, the victims of nuisance are not routinely given a similar put option. If Calabresi pollutes Melamed's land, Melamed is not given an analogous put option. This Article suggests that put options at times should be used to protect property in the nuisance context as well.

These common law puts can be seen as the second stage of a two-part process. In the first stage, a potential taker decides whether to take, and in the second stage, the initial entitlement holder decides whether to exercise her put-that is whether to seek return of her entitlement or permanent monetary damages. Appreciating the two stage nature of many put option regimes also clarifies the roles of puts in deterring or facilitating the initial first-stage taking.

This Article is divided into three Sections. The first Section will make the normative case for put options rules. The second Section will detail how the common law has used put options to protect property. The final Section will argue that put options rules-particularly Rule 6-should be used to resolve nuisance disputes and will consider how courts should set damages. While damages-in option lingo, the exercise price of the put-are often set to deter the initial taking, this Section will explore when courts should adopt less extreme damages which-like the damages in Boomer-encourage a limited amount of first-stage taking.

17. Epstein, supra note 6, at 2093-94. 


\section{THE NORMative CASE fOR PUTS}

This Section attempts to synthesize and extend previous arguments for the use of puts. In doing so, it also presents the intellectual history of this idea. Six articles in the last six years have already considered the potential utility of put options, ${ }^{18}$ but the articles have largely written past each other. The casual reader in this literature is unlikely to see the connections in part because the same basic rule has been described variously as a put option, ${ }^{19}$ a reverse liability rule, ${ }^{20}$ the double reverse twist, ${ }^{21}$ reverse-reverse damages, ${ }^{22}$ a startling rule ${ }^{23}$ and Rule 5. ${ }^{24}$ This Article attempts to unify the literature behind the more descriptive terms "put option" or "forced purchase" rules. ${ }^{25}$ Taken as a whole, this literature suggests reasons why put options should be a vibrant part of our jurisprudence. This does not mean, however, that Rules 5 and 6 should devour the other four categories-only that they deserve their place in the cathedral.

To begin, it is useful to clear away the only explicit criticism of put option rules-that of Richard Epstein. After Epstein's aforementioned claim that liability rules "when used, always take the direction of a 'call," ${ }^{26}$ he goes on to explain:

The reason seems clear. A liability rule is typically adopted to counter the monopoly position of the holder of the asset. The holder of cash has no monopoly position at all, so it is very hard to believe that by allowing the present holder of some specific asset to designate the person who must take it off his hands, we advance any conceivable measure of social welfare. ${ }^{27}$

This argument has considerable superficial appeal. Money is a unique asset in part because owners rarely develop idiosyncratic, subjective value for cash in

18. See Ayres \& Balkin, supra note 6, at 731; Ayres \& Talley, supra note 6, at 1063; Epstein, supra note 6, at 2093, 2099-100; Krier \& Schwab, supra note 4, at 470; Levmore, supra note 6, at 2160 ; Morris, supra note 5 , at 853.

19. See Ayres \& Talley, supra note 6, at 1063; Ayres \& Balkin, supra note 6, at 731.

20. See Morris, supra note 5 , at 854.

21. See Krier \& Schwab, supra note 4 , at 470.

22. Id.

23. See Levmore, supra note 6, at 2160.

24. Id. at 2163.

25. Admittedly not much turns on a name. But while the various "reverse" permutations are colorful, they do not as clearly connote the core attribute that this type of rule gives an entitlement holder the option to sell (which amounts to an option to force a purchase).

26. Epstein, supra note 6, at 2092.

27. Id. at 2094 (emphasis added). 
the same way that they might for a grandparent's jewelry or other thinly traded entitlements. But the argument unravels when read in conjunction with Epstein's argument in favor of call options. Epstein believes that traditional liability rules-which amount to call options-are appropriate where there is a severe holdout problem caused by a bilateral monopoly. According to Epstein, "[ $\mathrm{t}]$ hese holdout situations arise when the resource currently commanded by $\mathrm{A}$ is needed by $\mathrm{B}$, such that each can deal only with the other for the useful exchange to take place." 28 But if call options can be useful to overcome bilateral monopoly problems, why cannot put options be useful? Epstein's core argument against puts, that "the holder of cash has no monopoly position at all," is belied by his own bilateral monopoly example (which happens to appear on the following page of his article). If $A$, the initial entitlement holder, "can deal only with" $B$, then the holder of cash has a monopoly position. If $B$ is the only possible buyer, we might want to give $A$ a put option to overcome $B$ 's inefficient incentive to holdout for a low price. ${ }^{29}$ Epstein is right that it makes little sense to allow the present holder of some asset to have complete freedom in "designat[ing] the person who must take it off his hands," but it can make eminent sense in the bilateral monopoly settings (where evidence suggests there is a single potential buyer) for the law to give the seller a put option to mitigate buyer's monopoly position-just as the law in other bilateral monopoly situations gives the buyer a call option to overcome the seller's monopoly position.

Carol Rose has acutely observed that my previous option analysis has a contractual shadow as its paradigmatic example: "The contractual relationship has only a discrete number of parties-paradigmatically two-who . . . are stuck with each other." ${ }^{30}$ Rose is clearly right that contractual renegotiations often involve limited numbers and a bilateral monopoly. For example, once Epstein agrees to cut Rose's hair, Rose is the only one with whom Epstein can bargain if he wants to buy back his promise. ${ }^{31}$ But, while contracts may serve as a fine paradigmatic example, the option approach is a powerful way to analyze any bilateral monopoly situation-that is any situation where there are two (or a small number of) people who "are stuck with each other." 32 For the

28. Id. (emphasis added). A bilateral monopoly exists when "circumstances limit each side to a single trading partner." Id. at 2092.

29. The common law does not give the entitlement holder carte blanche to designate the person who must take it off his hands, just as the law does not give the owner of a call the power to take anybody's property. Rather, when evidence of a bilateral monopoly exists, the law at times might grant either a call or a put to overcome the monopoly position that each party has.

30. Rose, supra note 6 , at 2187.

31. See Ayres \& Balkin, supra note 6, at 745 .

32. Rose, supra note 6 , at 2183 . Rose characteristically hits the nail on the head when she says: "Ayres and Talley are interested in situations in which two parties are stuck with each other, thin markets instead of 'thick' ones. Neighboring landowners seem to fit that bill." Id. at 2183. But she engages in a bit of playful overstatement when she later says: "Ayres and Talley are not 
purposes of this Article, I accept Epstein's premise that liability rules are only appropriate in situations of a bilateral monopoly..$^{33}$ Throughout virtually all of the Article, I assume that the bilateral monopoly "holdup" problem is so severe that courts do not want to rely on consensual trade to assure allocational efficiency. Judge Richard Posner has argued that the holdup problem may be especially acute when a property rule (Rules 1 or 3 ) creates a substantial bargaining range. In discussing Boomer, Judge Posner found:

An injunction against the nuisance could therefore have created a huge bargaining range . . . and the costs of negotiating to a point within it might have been immense. If the market value of the [Polluter's] factory was actually $\$ 45$ million, the plaintiffs [Residents] would be tempted to hold out for a price to dissolve the injunction in the tens of millions and the factory would be tempted to refuse to pay anything more than a few hundred thousand dollars. Negotiations would be unlikely to break down completely, given such a bargaining range, but they might well be protracted and costly. ${ }^{34}$

Boomer provides the paradigmatic example for my analysis. Because of the large bargaining range and/or because of enmity between the bilateral monopolists, courts are worried that property rules create the possibility of unacceptably large bargaining costs, and even worse, the small chance that the parties will each hold out for so much and so long that the factory is inefficiently closed down. In just this type of circumstance, where most law and economic scholars would embrace liability rules over property rules, I want to argue that Epstein's theory fails to explain why calls should dominate puts as a way to overcome the holdout problem.

Indeed, from an option perspective, put options share the same core advantage of traditional liability rules: they harness the private information of the option holder. Kaplow and Shavell formalized the insights of Calabresi and Melamed in showing that a liability rule can induce efficient takings. ${ }^{35}$ If the option exercise price is set at the court's best estimate of the non-option holder's

really thinking about real estate. Those footnote references to Boomer and Spur Industries are essentially a smokescreen." Id. at 2187 . I think we were "really thinking about" bilateral monopoly. Because these come up in nuisance disputes between neighboring landowners, this is one of the contexts that we were really thinking about.

33. But see Ayres \& Talley, supra note 6, at 1058 (arguing that liability rules may be more efficient than property rules even when transaction costs are small); Ian Ayres \& Eric Talley, Distinguishing Between Consensual and Nonconsensual Advantages of Liability Rules, 105 Y ALE L.J. 235 (1995).

34. Walgreen Co. v. Sara Creek Property Co., 966 F.2d 273, 278 (7th Cir. 1992).

35. See Louis Kaplow \& Steven Shavell, Property Rules Versus Liability Rules: An Economic Analysis, 109 HARV. L. REV. 713 (1996). 
value, ${ }^{36}$ the option holder will exercise the call option only when the forced sale is, on average, efficient. Under Rule 2 , for example, the Polluter will only choose to pollute if it believes its value to be larger than the expected value of the Resident. But put options can analogously harness the private information of the put holder. If the put's exercise price is set equal to the non-option holder's value, the put holder will only exercise the put option when a forced purchase is on average efficient. Thus, under Rule 6, a Resident will force the Polluter to buy the right to pollute only when the Resident values the entitlement less than the average value of the Polluter. The great non-consensual advantage of either calls or puts is that, when private bargaining is not practicable, the courts can enhance efficiency even if they can only estimate the expected value of one side. ${ }^{37}$ Boomer gave the Polluter a call option-an option to acquire the ability to pollute even over the residents' objections-because the court worried, in the shadow of a Rule 1 injunction, that the parties may not be able to agree to a consensual trade. But whenever a court thinks that Rule 2 is potentially appropriate, it should consider whether giving the residents the choice to force a non-consensual purchase furthers the same end.

But appreciating the deep similarities between puts and calls does not help identify the circumstances in which courts should prefer puts to calls. While both puts and calls can harness the private information of the option holder, this Section will identify differences which might lead courts to choose puts (Rules $5 \& 6$ ) instead of calls (Rules $3 \& 4$ ). For convenience, the discussion is organized around three categories: distributional, informational, and bid-ask differences.

\section{A. Distributional Differences}

A number of scholars have noted that put option rules give the initial entitlement holder a larger expected payoff than either property or liability rule regimes. ${ }^{38}$ As shown in Table 3, Rule 1 gives the Resident the entitlement (without calls or puts); Rule 3 gives the Resident the entitlement minus, or subject to, the Polluter's call option; but Rule 6 gives the Resident the entitlement plus a put option. The distributional difference can provide an important difference for choosing between puts and calls. 100.

36. The appropriate size of the exercise price is discussed infra text accompanying notes 93-

37. See Ayres \& Talley, supra note 33 , at 235.

38. See Krier \& Schwab, supra note 4, at 473; Levmore, supra note 6, at 2163; Morris, supra note 5 , at $855-56$. 
Krier and Schwab have persuasively argued that this distributional difference can help courts better accommodate concerns of both efficiency and equity. In a high transaction cost setting, if a court concluded that the Resident was the more efficient decisionmaker ${ }^{39}$ it would be driven under Calabresi and Melamed's analysis toward Rule 4. The Resident could stop the pollution, but only if it were willing to pay-and sacrifice a large part of its expected payoff. Krier and Schwab's central insight is that using puts allows a court to give the choice to one side without forcing that party to pay for a right that in equity should be its to begin with. Under Rule 6, the Resident can be given the pollution decision without sacrificing its expected payoff. ${ }^{40}$ Indeed, giving the Resident the initial entitlement plus a put guarantees that the Resident will never be undercompensated.

But surprisingly, put option rules need not reduce the expected payoff of the non-option holder-the party that might be subject to a forced purchase. To see why this is so, it is important to distinguish between two different information perspectives. The ex ante perspective assesses the parties' expected payoffs before they acquire information about their own payoffs. The interim perspective assesses the parties' expected payoffs after they learn their own values but before learning the other side's value. From the ex ante perspective, the possibility of being subject to a forced purchase does not produce a negative expected payoff. Under Rule 6, a Polluter may be forced to purchase the right to pollute. But if the price is set at the Polluter's expected valuation, the Polluter's expected payoff is zero. Rule 6 can increase the Resident's payoff above what she would expect under a traditional property regime (Rule 1), without reducing what the Polluter would expect under a property rule regime.

To see this, imagine that after all the evidence has been submitted, the court's best estimate is that the Polluter values the right to pollute somewhere between $\$ 0$ and $\$ 100$ million, and that the Resident values the right to stop pollution somewhere between $\$ 0$ and $\$ 100$ million. More formally, assume that the Polluter's and Resident's values are independently and uniformly distributed. And, finally, assume that, either because of enmity or the bargaining range problem identified previously by Judge Posner, the parties are unlikely to consensually transfer the entitlement if the court chooses either of the property rules. With these assumptions, it is possible to analyze the expected (ex ante) payoffs of the three rules giving the initial entitlement to the Resident:

39. Krier and Schwab focus on the relative number or Polluters and Residents as the primary determinant of efficient decision-making. See Krier \& Schwab, supra note 4, at 473.

40. Rule 6 can force a Polluter to pay for the right to pollute, but this rule does not obligate the Polluter to pollute if she does not want to exercise this new found right. 
Table 4. Expected Payoffs Under Different Rules. Giving Initial Entitlement to Resident

\begin{tabular}{|c|c|c|c|}
\hline & \multicolumn{3}{|c|}{ Expected Payoffs (Ex Ante) } \\
\hline & Resident & Polluter & Joint \\
\hline Rule 1 & $\$ 50$ & $\$ 0$ & $\$ 50$ \\
\hline $\begin{array}{c}\text { Rule 2 } \\
\text { (damages = \$50) }\end{array}$ & $\$ 50$ & $\$ 12.50$ & $\$ 62.50$ \\
\hline $\begin{array}{c}\text { Rule 6 } \\
\text { (damages = \$50) }\end{array}$ & $\$ 62.50$ & $\$ 0$ & $\$ 62.50$ \\
\hline
\end{tabular}

As shown in Table 4, the Boomer-like Rule 2 does help overcome the bilateral monopoly holdup problem. If consensual trade is impracticable, then Rule 1 will simply produce an expected value of $\$ 50$ million for the Resident (the Resident's mean value of stopping) pollution. Under Rule 1 (with no consensual trade), the Polluter will never pollute and therefore will have a zero expected payoff. However, Rule 2 (with damages equaling $\$ 50$ million) harnesses the Polluter's private information. The court should expect that the Polluter will choose to pollute (and pay $\$ 50$ million) if its valuation is greater than the $\$ 50$ million damages. The court expects this to happen with a 50\% probability and when the Polluter does choose to pay damages, it will on average have a $\$ 75$ million value. A $50 \%$ chance of a $\$ 25$ million profit ( $\$ 75$ million - $\$ 50$ damages) gives the Polluter an expected payoff under Rule 2 of $\$ 12.5$ million. But Rule 2 does not reduce the Resident's expected payoff. If the Polluter does not take, the Resident still expects to control what on average will be a $\$ 50$ million entitlement, and when the Polluter does take, the Resident is given $\$ 50$ million in compensation. ${ }^{41}$ Thus, Rule 2 succeeds, even in the absence of consensual trade in helping the entitlement flow to the higher valuer-raising the expected joint payoffs from $\$ 50$ to $\$ 62.5$ million.

But Table 4 shows that Rule 6 is just as effective in overcoming the bilateral monopoly problem. If the parties are unable to contract in the shadow of Rule 1, then Rule 6 (with $\$ 50$ million damages) will induce the Resident to pollute when its value is less than $\$ 50$ million. While Rule 2 harnesses the Polluter's private information, the put option harnesses the Resident's private information. Under Rule 6, half of the time the Resident puts its entitlement for $\$ 50$ million, and half of the time the Resident retains the entitlement when its

41. The assumption that the Polluter's and Resident's valuations are independent is crucial to this analysis. Kaplow and Shavell discuss the more complicated question of correlated valuations. See Kaplow and Shavell, supra note 35. 
value is on average $\$ 75$ million. A $50 \%$ chance of $\$ 50$ million and a $50 \%$ chance of $\$ 75$ million, thus, gives the Resident an expected payoff of $\$ 62.5$ million. On the other hand, the Polluter has $\$ 0$ expected payoff. Fifty percent of the time the Polluter does not pollute (and has a $\$ 0$ payoff), and $50 \%$ of the time the Polluter must pay $\$ 50$ million for an entitlement that it values on average at $\$ 50$ million (again producing an expected $\$ 0$ payoff).

Table 4 shows that Rules 2 and 6 each help overcome the potential autarkic inefficiencies of Rule 1, but that puts and calls allocate these improvements in efficiencies to different parties. Rule 2 keeps the Resident's expected payoff fixed at its Rule 1 level and distributes all of the gains in efficiency to the Polluter. Rule 6, in contrast, keeps the Polluter's expected payoff fixed at its Rule 1 level and distributes all of the gains in efficiency to the Resident. Thus, Rule 6 can increase the Resident's payoff above what she would expect under a traditional property regime (Rule 1) without reducing what the Polluter would expect.

However, the results of Table 4 do not necessarily hold for the interim perspective-that is, where expected payoffs are calculated conditional to the parties knowing their value of pollution. From the interim perspective, Rule 6 might create a negative expected payoff. If the Polluter knows that its valuation is less than the mean value (for similarly situated Polluters), then it realizes that it might be forced to pay more for the right to pollute than its known value. The interim perspective may be more relevant to judging the equities at the time a put option is exercised. However, the ex ante expected payoffs may be more relevant for predicting how put option rules will affect investment decisions. For example, if at the moment of investing, the Polluter does not know what its value will be, then put options will not produce a lower expected payoff for the Polluter then it would expect under a property rule.

The distributional difference between puts and calls can have important affects on the parties' ex ante investment incentives. If lawmakers think that it is particularly important to give the Resident an incentive to invest in her land, then giving the Resident the initial entitlement plus a put will give her a stronger ex ante incentive to invest. ${ }^{42}$ For example, in our Table 4 scenario, a Resident may be willing ex ante to invest only up to $\$ 50$ million under Rule 1 , but might be willing to invest up to $\$ 62.5$ under Rule 6. Put option rules, thus, not only allow lawmakers to accommodate competing equity and efficiency concerns, they can even help lawmakers to accommodate competing efficiency concerns-the concern with ex ante investment efficiency and the concern with ex post taking efficiency.

42. See Ayres \& Balkin, supra note 6, at 733 . 
Finally, the distributional differences between puts and calls can also give rise to a risk-aversion theory for preferring puts. The payoffs for puts and calls not only have different means, but different variances. Put option rules not only increase the expected pay of the initial entitlement holder, they also reduce the variance of the initial entitlement holder's payoff. Put more formally, from either $e x$ ante or interim perspective:

1. The mean of payoffs for initial entitlement holder is higher with a put than a call; and

2. The variance of payoffs for initial entitlement holders is lower with a put than a call.

This reduction in variance makes intuitive sense: under a call option, the fate of the initial entitlement's holder is decided by the other side, but under a put option, the initial entitlement holder decides her own fate and, thereby, can limit fluctuations in her own payoff. Therefore, if lawmakers believe that the Resident is substantially more risk averse than the Polluter, then the law would do better to prefer a put option rule-such as Rule 6 to a traditional liability rule (Rule 2). ${ }^{43}$

\section{B. Information-Forcing Differences}

Puts and calls also have different information-forcing effects that might affect whether the parties are able to trade. While most of this Article assumes that transaction costs make consensual trades extremely difficult, this Section explores how puts and calls might still be more efficient than traditional property regimes when transaction costs are relatively low. ${ }^{44}$ Ayres and Talley showed that option regimes have an information-forcing effect on the non-option holder. Calls and puts, by dividing the claims to an entitlement between the two parties (as shown in Table 3), create two different types of value-enhancing trade. For some private valuations, it will be efficient for the one side to buy the other

43. See Morris, supra note 5, at 855 ("Arrangements such as puts, for instance, permit investors to control their ratios of risk to potential profits in ways consistent with their own risk preferences.").

44. The law and economics community persists in thinking that property rules dominate option (put or call) rules when transaction costs are low. But, at least, in circumstances of bilateral monopoly, no scholar to date has identified a reason why we would expect trade to be more efficient in the shadow of property rules than in the shadow of option rules. By the Coase theorem, we know that trade will be equally efficient under any regime when transacting is costless. But for some reason, scholars persist in thinking that property rules dominate when an epsilon amount of transaction costs are added.

As emphasized in my previous writing (see Ayres \& Talley, supra note 6), a strong case for property rules can be made in terms of producing superior ex ante investment incentives but it is much more difficult to justify the rules in terms of ex post trading efficiency. 
side's option (effectively bribing the option holder not to exercise). For other valuations, it will be efficient to trade the underlying entitlement.

Ayres and Talley showed that under call and put option regimes the nonoption holder could credibly signal information about her value by merely expressing interest in one type of trade or the other. ${ }^{45}$ For example, under a Rule 2 call option regime, the Resident as the non-option holder could credibly signal whether she had a relatively high or low value merely by expressing an interest in buying the Polluter's option to pollute or expressing an interest in selling her initial entitlement to stop pollution. However, under a Rule 6 put option regime, it is the Polluter instead as the non-option holder who now can credibly signal her value. A low-valuing Polluter might bribe the Resident not to exercise her put option, while a high-valuing Polluter might purchase the Resident's initial entitlement to stop pollution.

Appreciating that this information-forcing effect operates on the non-option holder suggests that courts can induce Residents to reveal information by adopting either Rules 2 or 5 and can induce Polluters to reveal information by adopting either Rules 4 or 6 . Private information of one side often is a major barrier to consensual trade. ${ }^{46}$ From an information-forcing perspective, courts might want to give the option to the party whose valuation is more certain so as to induce the non-option holder to speak more honestly about its valuation. Put option rules allow judges more flexibility to accommodate ex post informationforcing and ex ante investment or ex post equity concerns. ${ }^{47}$

\section{Bid-Ask Differences}

Finally, put and call options differ in that calls turn on a buyer's willingness to pay while puts turn on a seller's willingness to accept. For both cognitive and wealth effect reasons, it is often the case that a particular person will

45. Id. at 1063 .

46. For example, it might be relatively straightforward to estimate the lost economic profit of a Polluter, but substantially more difficult for a Resident to speak credibly about whether its subjective losses from pollution are high or low.

47. Madeline Morris has also suggested that put option rules might be effective in inducing entitlement holders to reveal when they own an entitlement that the government wants to purchase-such as guns or empty soda bottles. See Morris, supra note 5, at 855 ( “ [g]un buy-out offers by police departments and soft-drink container deposit redemption laws represent instances where Reverse Liability rules are used to create incentives for individuals to dispose of certain goods in socially desirable ways"). As a conceptual matter, the govemment could exercise its eminent domain call option to non-consensually take these items. The practical problem is that the government does not know who has the unlicenced guns or empty soda bottles. Under these circumstances, some governments have given citizens put options-via gun buy-back programs or bottling deposit laws-which give citizens the option to sell. 
demand a higher price when selling an entitlement than she would be willing to pay if forced to buy. ${ }^{48}$ As Saul Levmore has noted in discussing put options:

Armed with the legal right to be free of pollution, [a Resident] might have demanded $\$ 100,000$, for example before allowing [a Polluter] to send effluents her way, so that [the Resident's] damages from [the Polluter's] operation can fairly be said to amount to $\$ 100,000$; but this does not mean that [the Resident] could or would pay this amount to stop [the Polluter], if the law requires [the Resident] to pay in order to [stop pollution]. ${ }^{49}$

This suggests that a range of intermediate exercise prices-above a person's willingness to pay but below her willingness to accept-will often exist for which the law's determination of an initial entitlement will stick. For this range of exercise prices, under Rule 6 the person would not put (opt to sell) the entitlement if she were originally endowed with it, and under Rule 4 she would not call (opt to buy) the entitlement if she were not originally endowed with it. This should not be surprising. It has long been known that endowment effects impede trade in the shadow of property rules; this result carries over to option regimes.

What is more controversial is whether lawmakers should privilege endowment effects in cost-benefit calculus. If a Resident values an entitlement (more than a Polluter) merely because she is initially endowed with it, lawmakers might want to set a low call option price to allow the Polluter to take control of the entitlement and benefit from its own endowment effect. One goal - to be traded off against other equity goals-would be to produce a legal regime where the entitlement flowed to the person who would have the highest willingness to accept. ${ }^{50}$ From an efficiency standpoint, this would rank people

48. Mark Kelman, Consumption Theory, Production Theory and Ideology in the Coase Theorem, 52 S. CAL. L. REv. 669, 673 (1979); Duncan Kennedy, Cost-Benefit Analysis of Entitlement Problems: A Critique, 33 STAN. L. REV. 387, 401 (1981); Russell Korobkin, Note, Policymaking and the Offer/Asking Price Gap: Toward a Theory of Efficient Entitlement Allocation, 46 STAN. L. REV. 663 (1994).

49. Levmore, supra note 6 , at 2166.

50. See Herbert Hovenkamp, Legal Policy and the Endowment Effect, 20 J. LEGAL STUD. 225, 232-34, 245-47 (1991) (claiming that WTA should always be used rather than WTP). Russell Korobkin, however, has suggested reasons why allocating entitlements on the basis of willingness to accept is inappropriate when there are independent social norms against selling certain types of entitlements:

Narrowly stated, our society teaches us that we should not sell some things, although buying them is socially acceptable. Although an individual might, in a cultural vacuum, prefer a specific quantity of money to a certain entitlement, he might feel that selling the entitlement is improper and, therefore, his WTA will exceed his WTP. This explanation has been called the "dignity hypothesis." 
by their value of "having" rather than their value of "not having." Other things being equal, this would lead toward giving the initial entitlement to the party with the larger endowment effect. ${ }^{51}$

The advantage of put option rules is, again, that they can help lawmakers accommodate competing concerns. Efficiency considerations might militate toward giving the initial entitlement to the party with the larger endowment effect. But if this is the party that the court believes is also the more efficient chooser ${ }^{52}$ then the court can accommodate both efficiency concerns by giving the party both the initial entitlement and a put option. ${ }^{53}$ Without the "put option" rules, the court would have to choose between either giving this preferred party the initial entitlement (to take advantage of the endowment effect) or a call (to take advantage of the better chooser effect).

Finally, it is not clear whether the endowment effect persists in the shadow of option regimes. The path-breaking mug experiments of Kahneman, Knetsh, and Thaler only tested whether entitlements protected by property rules gave rise to endowment effects. ${ }^{54}$ It is much less clear whether endowments protected by liability rules-i.e., subject to someone else's call option-give rise to the same effect. In the shadow of a call option, the initial entitlement holder has a more transient, less secure claim to the entitlement and, thus, may not establish the cognitive bond that in part may give rise to the effect. In fact, Jeff Rachlinski and Forest Jourden have recently conducted experiments showing that the endowment effect is largely extinguished in the shadow of traditional liability (call option) rules. ${ }^{5 s}$ However, put options may heighten the endowment

Korobkin, supra note 48, at 691-92.

51. For example, imagine that a Polluter and a Resident in a world without endowment effects would both have values for the entitlement ranging between say $\$ 40$ and $\$ 60$, but that endowment effects cause the Resident's WTP to be $\$ 5$ lower than it would otherwise be, and cause the Resident's WTA to be $\$ 5$ higher than it would otherwise be. The endowment effect on Resident would raise the Resident's average value of having the entitlement to $\$ 55$ which is higher than the average $\$ 50$ of having the entitlement for the Polluter. Under these assumptions, joint payoffs are maximized by giving the entitlement to the Resident-the party with the larger endowment effect. Rules 2 and 6 give rise to larger joint payoffs than rules 4 and 5 .

52. As discussed above, a court might consider one side to be the more efficient chooser either because it has lower decision costs-multiple decision-makers have higher collective action problems than unitary decision-makers-or because it has a higher option value. See infra note 58 and accompanying text.

53. As before, put option rules could also allow lawmakers to more easily accommodate efficiency concerns or investment concems together with the endowment effect concern.

54. Daniel Kahneman et al., Experimental Tests of the Endowment Effect and the Coase Theorem, 98 J. POL. ECON. 1325 (1990).

55. Jeffrey J. Rachlinski \& Forest Jourden. The Psychology of Ownership (Dec. 1997) (unpublished manuscript, on file with authors) (arguing that "the endowment effect may only occur among legal entitlements that are protected by injunctive remedies"). This possibility was first suggested in Ayres \& Talley, supra note 6, at 1102. 
effects. Put options give the initial entitlement holder even more control over her "endowment" than traditional property rules, and this may enhance the solidity of ownership. ${ }^{56}$ If the endowment effect is a source of real value that we want to nurture-as opposed to a "status quo bias" or "framing effect" that we want to overcome ${ }^{57}$-then put options may be a way to overcome the inefficiencies of the holdup problem in bilateral monopoly settings without destroying the "value of having."

In sum, theory suggests that courts, when choosing between different option regimes (Rules 3 through 6), must decide which party should receive the initial entitlement and which side should be given the option. The initial entitlement might be allocated by efficiency-minded or equity-minded judges to the party (1) who is more deserving; (2) who values the entitlement more at the time of the dispute; (3) for whom investment incentives are more important (i.e., the party who had a greater ex ante ability to develop the entitlement); or (4) who is likely to have a larger endowment effect. And following Krier and Schwab, the option should be allocated to the better chooser. When the better chooser turns out to be the same party to whom the court wants to give the initial entitlement-for either equity or efficiency reasons-then put options regimes (Rules 5 and 6) are the natural solution.

However, just as there are multiple criteria for determining who is the better owner of the initial entitlement, there are also multiple criteria for determining who is the better owner of the option, that is, who is the better chooser. Krier and Schwab focus almost solely on the relative number of Polluters and Residents as the primary determinant of efficient decision-making. Individual decision-makers are presumptively more efficient than multiple decision-makers because they do not need to overcome collective action problems. But there are other dimensions on which to determine who is the more efficient decision-maker. Options are more valuable when there is a greater variance in the value of the underlying asset. ${ }^{58}$ This suggests that, other things being equal, the party with more speculative damages is the more

56. Russell Korobkin, however, has suggested to me that the put option may commodify the entitlement in the owner's mind in ways that reduce the endowment effect. Imagine that after a pure-bred dog has puppies that a mother tells her daughter she can keep the puppies or sell them for $\$ 50$, after they are weened, to a neighbor who has made a firm offer. The daughter's knowledge that she has a put option might stop her from bonding as closely with the puppies during the weening period and hence mitigate the endowment effect.

57. See Russell Korobkin, The Status Quo Bias and Contract Default Rules, 83 CORNELL L. REV. 608 (1998).

58. See BREALEY \& MYERS, supra note 6, at 555. 
efficient option holder. ${ }^{59}$ Or alternately, as indicated above,$^{60}$ because options reduce the variance of the option holder's payoff (and conversely tend to increase the variance of the non-option holder's payoff), the more risk-averse party is, at lease on this dimension, the better chooser. Krier and Schwab's central point, however, still holds true. Courts may decide that a Resident is the efficient option holder without forcing this person to pay for the entitlement-using Rule 6, it can give the party a put option to force a purchase, when its value is low.

\section{The Descriptive Prevalence of Puts}

Richard Epstein surely states the conventional wisdom when he concludes that "[p]uts . . . are never imposed as a matter of law on strangers but are the outgrowth of consensual transactions over organized markets." ${ }^{n 1}$ Madeline Morris, in searching for puts created by law instead of consensual transactions, could only come up with the rather esoteric regulatory examples of "[g]un buy-out offers by police departments and soft-drink container deposit redemption laws." 62 Thus, even if the normative arguments or the previous Section are correct, it seems that as a descriptive matter, like Rule 4 before Spur, Rules 5 and 6 are largely missing common law categories.

59. For an explicit example of the effect, see infra text accompanying note 76 . This result is only true in a world where bargaining is not possible. When transaction costs are low, the party with the smaller variance in value may be the more efficient option holder, because of the aforementioned information-forcing effect. See supra text accompanying note 44.

60. See supra text accompanying footnote 43 .

61. Epstein, supra note 6, at 2093.

62. Morris, supra note 5 , at 855 . 
This Section argues, however, that the common law does impose puts that are not the outgrowth of consensual transactions. ${ }^{63}$ In a variety of contexts, when a person temporarily takes, invades, or impairs the entitlement of another, the original entitlement holder is given the remedial choice of either regaining the original unimpaired entitlement or permanently selling the entitlement to the wrongful taker. Either remedial choice normally gives the wronged entitlement holder monetary damages for the temporary taking. But with regard to the future, this choice of remedy amounts to a put option: the initial entitlement holder can choose to be paid or to permanently relinquish its rights, while the wrongful taker might be forced to purchase an entitlement that she does not want. Call options give the taker the option of paying for someone else's rights, but the choice here is the option of being paid for relinquishing prospective rights to an entitlement. This insight is not well known in the legal academy with one rather curious exception. The only article which sees that the common law of conversion gives "the owner of the thing . . . a 'put' that forced the person who took the thing to purchase it for market value" also happens to be the same article in which Epstein says there are no legally imposed puts. ${ }^{64}$

63. Epstein is right that the common law does not impose puts on complete stangers, just as he was right in saying that it serves little purpose in giving an initial entitlement holder carte blanche in designating who must purchase the entitlement. But Epstein here is attacking a straw person. His analysis seems to imply that law in establishing put regimes must give an entitlement holder puts against the world or at lease to stangers who are not plausibly the highest valuers of the entitlement. There is no reason, however, why the put holder's option to force a purchase cannot be restricted to operate only against potential buyers in the bilateral monopoly context. Indeed, the advocates of option regimes have explicitly argued that options (puts or calls) should only operate against nonoption holders who are potentially the highest valuers:

Lawmakers attempting to implement a Solomonic regime also face a serious

"identification" problem. . . Restricting the class of partial owners to the set of potentially highest valuers will be impossible in some contexts. Nevertheless, lawmakers or private parties themselves may be able to identify parties who ultimately may become the highest valuers. . . . [S]ome contexts naturally suggest a well-defined set of potential owners that may help lawmakers mitigate the problems of over- and under-inclusion. A limited set of adjoining landowners, for example, might sufficiently define the set of potentially highest valuers with regard to local omissions or easements for a view.

Ayres \& Talley, supra note 6, at 1086.

64. Epstein, supra note 6, at 2099. Epstein goes onto argue: "The 'forced sale' rule has come under constant attack especially in cases of innocent takings, where it is usually rejected today. What possible reason is there to believe that I want the ill-fitting galoshes that I took by mistake from the opera cloakroom?" Id. at 2099-100. Epstein's analysis of this "forced sale" rule is puzzling for several reasons. To begin, he does not provide any citations for his claim that the rule has come "under constant attack." And for good reason, because the rule has not come under constant attack. Second, while he attacks the use of all puts, he only suggests a basis for criticizing innocent takings. He does not suggest a reason why there should not be put protection against deliberate takings.

And most bizarrely, in an article trying to shore up the normative case for property protection, Epstein fails to see that giving the aggrieved party a put is a way to deter takings. Even the person 
The implicit put option given to the aggrieved party in conversion can be seen in the choice between trover and replevin. Under the traditional common law, when personal property was converted to someone else's use, the owner could either sue for money damages (trover) or for return of the good (replevin). This choice of remedies gave the aggrieved owner a put against the wrongful possessor: by beginning an action of trover, the plaintiff "waives his right to obtain the return of the chattel and insists that the defendant be subjected to a forced purchase of the chattel from him." 65

And while trover and replevin concern the conversion of personal property, the parallel actions of trespass and ejectment provide the owners of real property with an analogous put. If Krier wrongfully possesses Schwab's land, Schwab would traditionally have the choice between an action for possession (ejectment) and an action for permanent damages (trespass). ${ }^{66}$ The put option afforded to the aggrieved real property owner is particularly evident in the classic encroachment case of Pile v. Pedrick. ${ }^{67}$ In Pile, the subterranean foundation of the defendant's brick wall was found to encroach 1 and 3/8th inches underneath the plaintiff's property. The court made explicit that the plaintiff could choose between injunctive and monetary relief:

who took the galoshes by mistake was negligent compared to the owner. We might want to give the aggrieved owner a put option to deter negligent takings. The choice of galoshes in his example is also unfortunate for Epstein because there is no way to know the original owner still wants the galoshes after Epstein places his feet in them. Kaplow and Shavell's analysis of optimal option prices also solves Epstein's galoshes problem. Kaplow and Shavell suggest that the optimal exercise price should be set at the court's best estimate of the non-option holder's value. Kaplow \& Shavell, supra note 35 , at 725 . In the galoshes example, this might be a relatively small number, so that most original owners would prefer the galoshes back rather than to exercise their put.

65. JesSe Dukeminier \& JAMES E. KRIER, Property 105 (3rd ed. 1993).

66. Id. at 107. The aggrieved property owner is not granted a put option when the government invades its property. In inverse condemnation actions, if a court finds that the government has temporarily taken part of a plaintiff's land, the government is given the call option of stopping (and just paying temporary damages) or continuing and paying permanent damages. First English Evangelical Lutheran Church of Glendale v. County of Los Angeles, 482 U.S. 304, 317 (1987) ("The Court has recognized in more than one case that the government may elect to abandon its intrusion or discontinue regulations .... [T] he landowner has no right under the Just Compensation Clause to insist that a 'temporary' taking be deemed a permanent taking."). The refusal to give aggrieved plaintiffs the choice might be justified as trying to make the parties' rights consistent with the government's general eminent domain call option rights. However, there may be times-particularly such as "condemnation blight" when the process of uncompleted condemnation reduces the value of private property-when it may be appropriate for the govemment's action to trigger a put option in the private landholder. See, e.g., City of Buffalo v. J.W. Clement Co., 269 N.E.2d 895 (N.Y. 1971); Gideon Kanner, Condemnation Blight: Just How Just Is Just Compensation?, 48 NOTRE DAME L. REV. 765, 788-90 (1973).

67. 31 A. 646 (Penn. 1895). I would like to thank Robert Ellickson for bringing this case to my attention and for generally holding my hand throughout my maiden voyage as a property professor. 
The trespass was then to be remedied in one of two ways. It could be treated with the plaintiffs' consent as a permanent trespass and compensated for in damages, or the defendants could be compelled to remove the offending ends of the stones to the other side of the line. The plaintiffs insisted upon the latter course, and the court below has by its decree ordered that this should be done. ${ }^{68}$

The plaintiff in Pile thus had an option of forcing the defendant to purchase the encroached land-even if the defendant preferred to take down the wall and just pay temporary damages. ${ }^{69}$

Put option rules are also used to protect landlords' rights with regard to holdover tenants. The common law gave the landlord burdened by a holdover tenant essentially two options: eviction (plus temporary damages), or the creation of a new tenancy for a period of up to one year ${ }^{70}$ The landlord could regain possession of her real property or force the holdover tenant (tenant at sufferance) to rent in the future-even if the tenant would just prefer to pay temporary damages and leave.

All of these put examples have the same basic structure. When Levmore impairs some entitlement of Rose, Rose is given the put option of either regaining unimpaired use of the entitlement (usually plus damages for the temporary taking) or giving up any future claims to the entitlement in return for permanent damages. Levmore's temporary taking gives Rose a put option. These examples show that put options are not the esoteric or missing category that Epstein and others in the legal academy make them out to be.

Richard Epstein is right that puts are not imposed upon "strangers," but he is wrong to think that they are only the outgrowths of consensual transactions. Rather, when Levmore takes Rose's property, Levmore is no longer a stranger to the property in question. If his taking is deliberate, he is expressing some value for the property. What is more, Levmore's act of taking may reduce Rose's value of the property. Rose may not want to use her toothbrush again after Levmore has temporarily used it. ${ }^{71}$ For both these reasons, there may be uncertainty after the taking about who more highly values the tainted goods.

68. Id. at 647 .

69. In the encroachment context, the plaintiff's put often has little value because the plaintiff can increase her expected payoff by demanding an injunction and then demanding a large payment from the defendant to avoid having to remove the trivial encroachment. See Ian Ayres \& Kristin Madison, Threatening Inefficient Performance (June 1998) (unpublished manuscript, on file with author).

70. DuKEMINIER \& KRIER, supra note 65, at 431 . See also RestATEMENT (SECOND) OF PROPERTY: LANDLORD AND TENANT $\$ 14.4 \mathrm{cmt}$. $\mathrm{f}$ (1977).

71. See supra note 64 (discussing Epstein's galoshes). 
And given the non-consensual nature of the initial taking, there may be substantial barriers to trade between these two parties. How can Rose bring herself to bargain with a thief?

All the equities favor Rose, the aggrieved owner. But the genius of the common law's giving Rose the choice of remedy is that it accommodates Rose's equity interest with the efficiency interest in having entitlements flow to the higher valuer. Puts or calls could satisfy the later interest, but giving the aggrieved owner the put furthers both equity and efficiency. Giving Rose the put option substantially reduces her risk of undercompensation-and instead places it on the wrongdoer, Levmore. If the original owner does not think court awarded damages are sufficient, she can simply choose to regain use of the property herself. Even if the two parties are not locked in a bilateral monopoly (because there may be third parties interested in buying the entitlement), the put option gives the aggrieved landowner the ability to shift the market risk (the risk and trouble of finding a buyer willing to pay the market) to the wrongdoer.

These puts are most closely analogous to Rule $6{ }^{2}$ Rule 6 gives the initial entitlement to the Resident, but if the Polluter impairs the Resident's entitlement (as in all of the foregoing common law examples), the Resident would have a choice between permanent damages or injunctive relief. While the common law uses put options to protect real property from physical trespass, encroachment, and holdover tenants, put options are not traditionally used in the nuisance context. Under the permanent nuisance doctrine, courts are not willing to award permanent damages for nuisance if an injunction against the defendant is likely to be effective in stopping the nuisance. ${ }^{73}$ Accordingly, plaintiffs in nuisance actions normally are not given the choice between injunctive and monetary relief. If the nuisance is abatable, then an injunction is granted. If the nuisance is not abatable, permanent damages are awarded. The plaintiff cannot choose between regaining her unimpaired enjoyment or forcing the defendant to purchase the prospective nuisance right-whether she wants to or not. The permanent nuisance doctrine's effect in restricting plaintiff choice is in stark contrast with the court's decision in Boomer. The Boomer court was willing to give the Polluter the choice about whether to pay damages or stop polluting, but

72. Under Rule 6, the initial pollution gives the Resident a put option. The Resident begins with the entitlement to be free of pollution, and if this entitlement is impaired by the Polluter's nuisance, the Resident gains a put option. However, Rule 5 does seem to be a missing category.

73. Raymond D. Hiley, Involuntary Sale Damages in Permanent Nuisance Cases: A Bigger Bang from Boomer, 14 B.C. ENVTL. AFF. L. REV. 61 (1986) ("[A] central question in permanent nuisance cases is whether injunctive relief is available to the plaintiff."). See, e.g., Spaulding v. Cameron, 239 P.2d 625, 627 (Cal. 1952); Bartlett v. Grasselli Chem. Co., 115 S.E. 451, 455 (W.Va. 1922) (overturning an award of permanent damages on the grounds that defendant's chemical manufacturing plant was an abatable nuisance, and thus did not constitute a permanent nuisance). 
the permanent nuisance doctrine often stops the Resident from having the choice on whether to receive damages or have the polluting stopped.

\section{II. PutTing UP WITH NUISANCE}

The previous two Sections point toward a simple innovation: courts at times should relax the permanent nuisance doctrine to give plaintiffs a put option of choosing injunctive or permanent damage relief. Section I showed the attractive qualities of put options. Section II showed the empirical prevalence of put options. Here, I suggest that what is good policy in these other common law contexts should also be available to judges deciding nuisance actions. Before awarding the Polluter the Boomer-like (Rule 2/call option) choice of whether to stop polluting or to pay for the right to continue polluting, courts should consider whether equity and efficiency would be furthered more by granting Rule 6 relief-that is, giving the Resident the choice to stop pollution or to force a purchase.

This Article is not the first to consider using put options to resolve nuisance disputes. Krier and Schwab (and then Levmore) include extended discussions of the issue. But their focus has been almost solely on Rule 5 puts. For example, Krier and Schwab ask us to consider the following scenario:

Suppose that if [a Polluter] (a party like Spur Industries) were to stay in operation as and where it is; this would cause damages of $\$ 100,000$ to the [Residents] (people like the citizens in the Spur Industries case). . . . Suppose also that the estimated value of [the Polluter's] operations as a going concern (the present discounted value of the future net profits) is either (a) $\$ 50,000$ or (b) $\$ 500,000$, and that in either event abatement short of closing down the operations would cost more than either of those amounts. . . .

The best-chooser axiom dictates that [the Polluter] be confronted with the relevant choice. The justice assumption dictates that [the Polluter] have the entitlement. Solution: The judge calculates, exactly as the judge would in a rule two case, the [Residents'] damages if [the Polluter] stays $(\$ 100,000)$. Next, the judge issues the peculiar order we identified earlier: [the Polluter] may continue operating if it so chooses, but if it closes down it will be awarded $\$ 100,000$, with a judgment against the [Residents] entered in that amount. ${ }^{74}$

74. Krier \& Schwab, supra note 4 , at 471-72. 
Their solution is a classic put option. In the Spur "coming to the nuisance" fact pattern, the equities favor the pre-existing Polluter ${ }^{75}$-who is also the "best chooser" because there are multiple Residents. Krier and Schwab's solution is to give the Polluter both the entitlement (an unimpaired right to continue polluting) plus a put option (the right to stop and force the Residents to pay $\$ 100,000)$.

\section{A. The Numerosity Problem}

I believe that Krier and Schwab's focus on Rule 5 exclusively is misplaced. The analysis of put options in other common law contexts suggest that Rule 6 is much more likely to be relevant. The "coming to the nuisance" context is atypical in that we think the equities may favor the Polluter. In the far more common circumstance, the equities (and efficiency) favor the Resident, the party whose property is being impaired. In a footnote, Krier and Schwab discuss the possibility of (what I have termed) Rule 6, but the authors view this regime as "an atypical case." They downplay the relevance of Rule 6-not because they think the equities typically favor polluters-but because they equate the best chooser with the least numerous party. Because the nuisance of pollution often comes from a discrete point of origin, but affects multiple neighbors, Krier and Schwab believe it will be atypical for the neighbors to have a decisional advantage vis-à-vis exercising the option.

But as argued above, ${ }^{76}$ the option perspective suggests that the best chooser will turn on more than just numerosity. In particular, because options are more valuable when there is great uncertainty in the value of the underlying asset, courts will do well ceteris paribus to give the option to the decision-maker who has a higher variance of potential values. To see this variance effect, imagine that a court believes that a Resident's harm from pollution is somewhere between $\$ 5$ and $\$ 105$ (uniformly distributed), but that the Polluter's costs of stopping pollution are somewhere between $\$ 40$ and $\$ 60$ uniformly distributed. Our first intuition might be to use Rule 2: give the initial entitlement to the Resident-because she has a higher expected value ( $\$ 55$ v. $\$ 50)$-and then to give a call option to the Polluter-to make up for the fact that parties may have trouble reaching agreement when the Polluter turns out to have the higher value. But in this example, the Resident's valuation has both a higher mean and a higher variance. Because options are worth more when the underlying entitlement is more variable, it turns out that Rule 6-giving the Resident the entitlement plus a put-is much more efficient than Rule 2 .

75. Carol Rose has suggested to me that equities do not necessarily favor the Polluter when the Residents come to the nuisance. The "coming to the nuisance" rule-not forcing established Polluters to compensate Residents-is prescription without adversity and without a statutory period.

76. See supra note 58 and accompanying text. 
Table 5. Expected Payoffs Under Different Rules Giving Initial Entitlement to Resident

\begin{tabular}{|c|c|c|c|}
\hline & \multicolumn{3}{|c|}{ Expected Payoffs (Ex Ante) } \\
\hline & Resident & Polluter & Joint \\
\hline Rule 1 & $\$ 55$ & $\$ 0$ & $\$ 55$ \\
\hline $\begin{array}{c}\text { Rule 2 } \\
\text { (damages = \$55) }\end{array}$ & $\$ 55$ & $\$ .625$ & $\$ 55.625$ \\
\hline $\begin{array}{c}\text { Rule 6 } \\
\text { (damages = \$50) }\end{array}$ & $\$ 65.125$ & $\$ 0$ & $\$ 65.125$ \\
\hline
\end{tabular}

Table 5 shows how the variance effect can cause Rule 6 to dominate Rule 2 . Under Rules 2 and 6 , the most efficient exercise prices are $\$ 55$ and $\$ 50$ respectively (because these damage amounts cause the taker to take only when its value is greater than the average valuation of the takee). In equilibrium, Rule 2 causes the Polluter to exercise her call option $25 \%$ of the time (when her valuation exceeds $\$ 55$ ). The Polluter's expected payoff is just $\$ .625-$ because the Polluter rarely exercises its option, and when it does, the Polluter's average value $(\$ 57.50)$ is only slightly above the damages that it must pay (\$55). ${ }^{7}$ Rule 2 does not help overcome the autarkic inefficiency of Rule 1 very much, because when the Polluter takes its average valuation it is not much greater than the Resident's average valuation.

In contrast, Rule 6 causes the Resident to exercise her put option $45 \%$ of the time (when her valuation is less than $\$ 50$ ). As before in Table 4, the put option fixes the Polluter's expected payoff at $\$ 0 .^{78}$ But, giving the Resident the option to sell more substantially overcomes the autarkic inefficiency of Rule 1. Under Rule 6, the Resident's expected payoff is $\$ 65.125$ : $45 \%$ of the time, the Resident will put its entitlement to the Polluter for $\$ 50$; and the other 55\% of the time the Resident will keep the entitlement (when it has an average valuation of $\$ 77.50)$. $^{79}$

In terms of overall efficiency, when the Resident exercises its Rule 6 option, it causes the entitlement to be transferred from Residents with an average valuation of $\$ 27.50$ to Polluters with an average valuation of $\$ 50$-and this $\$ 22.50$ improvement in efficiency happens $45 \%$ of the time. In contrast,

77. $.625=.25(57.5-55)$.

78. $0=.45(0)+.55(0)$. Fifty-five percent of the time, the Resident enjoins pollution so the Polluter has a zero payoff, and $44 \%$ of the time, the Resident forces the Polluter to pay $\$ 50$ for something that it values at $\$ 50$.

79. $65.125=.45(50)+.55(77.5)$. 
when the Polluter exercises its Rule 2 option, it causes the entitlement to be transferred from Residents with an average valuation of $\$ 55$ to Polluters with an average valuation of $\$ 57.50$-and this meager $\$ 2.50$ improvement happens only $25 \%$ of the time. The high variance Resident is the better chooser, because harnessing her private information can have a bigger impact on social value. Rule 2 increases the joint payoffs only about $1 \%$ above Rule 1, while Rule 6 represents more than an $18 \%$ improvement in efficiency. Under these circumstances, an efficiency-minded court would make a substantial error if it chose Rule 2 over Rule 6.

While numerosity will often militate against giving the option to multiple residents ${ }^{80}$ the variance effect will often militate in favor of giving the option to residents. It is often easier for courts to measure the economic costs of abating or discontinuing pollution than it is for courts to assess the non-economic damages of pollution to surrounding residents. Even though multiple residents will often have high costs of collective decision-making, they will also often have more relevant private information available (knowing how much pollution really harms them). ${ }^{81}$

At times, it will be better for courts to deal with the collective action problems caused by giving multiple residents a put, rather than disregarding their private information and giving a call option to the Polluter. For example, I believe that the residents in Boomer v. Atlantic Cement ${ }^{22}$ might have been the better chooser than the polluter-notwithstanding their relative numerosity-because the court had a more difficult time estimating the value of the entitlement to the residents. Instead of granting Rule 2 relief, the court would have been well advised to at least consider Rule 6: give Boomer and his fellow residents the right to enjoin Atlantic Cement's pollution or the right to force Atlantic Cement to pay permanent damages.

80. It is important to emphasize that a nuisance need not always affect multiple residents. See, e.g., Copart Indus. v. Consolidated Edison Co., 362 N.E.2d 968 (N.Y. 1977) (pollution from ConEd plant disrupted adjacent new car preparation business); Estancias Dallas Corp v. Schultz, 500 S.W.2d 217 (Tex. App. 1973) (air conditioner noise reduced value of single adjacent residence). The class of cases dealing with visual nuisances is particularly likely to involve a single plaintiff and a single defendant. Fontainebleau Hotel Corp. v. Forty-Five Twenty-Five, Inc., 114 So. 2d 357 (Fla. Dist. Ct. App. 1959) (hotel addition obstructed view of adjacent hotel); Amphitheaters, Inc. v. Portand Meadows, 198 P.2d 847 (Or. 1948) (light from night-time dog track races interfered with adjacent drive-in movie).

81. In addition, residents will often be more risk averse than the polluters (who may have greater abilities to diversify loss) and hence will, other things being equal, tend to be the better choosers. See supra text accompanying note 60.

82. Boomer v. Atlantic Cement Co., 257 N.E.2d 870 (N.Y. 1970). 
Because there were multiple residents, the court would need to determine a way to aggregate the residents' preferences about whether to exercise the put. This is not an easy task. For example, the court might give the residents a put that would be exercised only if a particular super-majority of residents consented to selling their no-pollution right. Collective voting schemes of course are imperfect mechanisms of aggregating preferences-being subject to the voters' strategic behavior. ${ }^{83}$ But in the takeover and bankruptcy contexts, the law (often with the aid of private contract) takes on similar collective action problems to determine what proportion of entitlement holders have to consent before a tender offer or a cram down reorganization is consummated ${ }^{84}$ Even super-majority votes raise the possibility that some dissenting residents will be undercompensated, but this risk of undercompensation will often be less with a super-majority version of Rule 6 than with a unitary polluter decision under Rule 2. Better to have fellow residents decide whether court awarded damages are sufficient than the polluter itself. Indeed, a supra-majority exercise trigger might even be useful in Boomer-like contexts to restrain the residents from opting for an injunction merely to holdup Boomer for a supra-compensatory payoff. ${ }^{85}$

Additionally, courts could rely the Rule 23 prophylactics of class certification $^{86}$ to help assure that individual resident interests are adequately represented in making litigation decisions, including what amounts to a traditional election of remedies, the decision on whether to elect injunctive or damage relief. The heightened duties of lawyers representing certified classes, the typicality requirement for class representatives, and the judicial overview of the class action litigation are all designed to overcome problems of collective action.

83. See KenNeth J. ARrow, Social Choice ANd Individual VAlues (1951).

84. See, e.g., Lucian Bebchuck, Toward Undistorted Choice and Equal Treatment in Corporate Takeovers, 98 HARV. L. REV. 1695, 1719-20 (1985).

85. In the takeover context, allowing less than unanimous consent to tender offers mitigates the problem of shareholder holdout. See lan Ayres \& Peter Cramton, Relational Investing and Agency Theory, 15 CARDozo L. REv. 1033 (1994); Sanford J. Grossman \& Oliver D. Hart, Takeover Bids, the Free-Rider Problem and the Theory of the Corporation, 11 BELL J. ECON. 42 (1980). The possibility that plaintiffs who are offered even supra-compensatory damages might still prefer opting for an injunction (which might induce the defendant to pay an even higher amount to avoid shutting down the plant) has led me to consider having courts issue "inalienable injunctions." See Ayres \& Madison, supra note 69 . Under this regime, a plaintiff/resident would still be given the put option of stopping the pollution or receiving damages, but the injunction to stop pollution would be "inalienable" in the sense that the court would not allow the defendant to subsequently buy its way out of the injunctive duties. Giving the plaintiff this type of an inalienable put substantially reduces the plaintiff's incentive to seek inefficient injunctions merely to increase its bargaining power.

86. See Douglas M. Towns, Merit-based Class Action Certification: Old Wine in a New Bottle, 78 VA. L. REV. 1001 (1992). 
Many scholars view the numerosity problem as a trump card, suggesting that it creates an insurmountable barrier that precludes meaningful resident choice. But while multiple residents, all else being equal, certainly militates against the use of Rule 6, the foregoing analysis suggests that all else need not be equal. When the residents' value of no pollution is more speculative than the factory's value of pollution and/or when residents are more risk averse, a flawed resident choice under Rule 6 might be more equitable and efficient than a "perfect" Polluter choice under Rule 2. For those readers who still think that put options theory has little practical payoff, my answer is to rethink Boomer. Put option theory suggests that the judge might have been better advised to use a majority-vote version of Rule 6 . This alternative holding would have furthered the equities of insuring that the residents were not undercompensated while, at the same time harnessing the more speculative, private information.

\section{B. Facilitating v. Deterring the Initial Taking}

But in applying the foregoing discussion to nuisance, there is an important difference between the puts discussed in Section I and those discussed in Section II that needs to be more explicitly analyzed. The put theory discussed in Section I begins by envisioning two parties locked in a bilateral monopoly conflict. Put option rules-like call option rules-are established by the court to facilitate efficient transfers when, because of high transaction costs, the parties cannot privately contract. In Section I, the first and only relevant choice is whether a put holder will exercise her put.

In Section II, however, the common law examples of put option regimes are more complicated. The temporary taking (or impairment) of someone else's right has the effect of giving the initial entitlement holder a put. ${ }^{87}$ In the language of contract, by taking initially, the encroacher makes what amounts to a "firm" offer to buy. After an initial taking, the initial entitlement holder-like an offeree receiving a firm offer-has an option to sell, an option to force a purchase-even if the offeror no longer wants to buy. Instead of beginning the analysis with the put option, the common law examples begin with the taker's decision whether to take the initial entitlement. Thus, even though the common law put examples are analogous to Rule 6 regimes, the common law puts are the second stage of two reciprocal options.

Jack Balkin and I have previously presented a theory of reciprocal taking auctions. ${ }^{88}$ We examined a situation where a Polluter might have an option to take initially by paying say $\$ 50$, but that a Resident would then have a right to

87. In the language of finance, the initial taker has the option of putting a put.

88. See Ayres \& Balkin, supra note 6 , at 707. 
retake by paying (the Polluter) $\$ 75$. This is an example of reciprocal call options: the Polluter has an option to buy, followed by the Resident's option to buy back. But because of what finance economists call "put-call parity," ${ }^{89}$ any put regime can be recharacterized as a type of call option. The put option examples of Section II can accordingly be recharacterized as a special kind of second-order call options. A two-stage version of Rule 6 applied to the nuisance context is equivalent to an award giving the Polluter an option to take initially by paying $D$ dollars, but then giving the Resident the option to take back the entitlement for $D$ dollars. Such a Rule 6 award is just a constrained version of the second-order liability rules analyzed in Ayres and Balkin, in that the exercise prices of the first- and second-order options are constrained to equal the same amount. 90

Appreciating that put options are often the second stage of a two-step process has important implications for thinking about how a court should set damages. By setting damages, the court not only will affect whether the (second-stage) put option is exercised, but also whether (in the first stage) the other side takes the initial action that gives rise to the put option coming into existence. Saul Levmore realized just this point in analyzing the effects of Rule 5. Remember that Rule 5 gives the entitlement to pollute, plus a put option, to the Polluter (and that under Krier and Schwab's theory the exercise price for the put option should equal the amount the court thinks the Resident would be damaged by pollution). ${ }^{91}$ Levmore argued: "If a judge follows Krier-Schwab and allows the defendant [Polluter] to continue on as before or instead choose to stop but then collect [the Resident's] (projected but not yet suffered) damages, [the Resident] may well be sorry that she brought her complaint." 92 Levmore saw that giving the Polluter the second-stage option of collecting $\$ 100,000$ for stopping pollution could deter the Resident's first-stage choice of bringing suit. Under this version of Rule 5, the Polluter's put option only emerges if the Resident files an initial complaint.

89. See BREALEY \& MYERS, supra note 6, at 557 (defining put-call parity); Ayres \& Talley, supra note 6, at 1047 (applying put-call parity to liability rules).

90. As a general matter, the unconstrained second-order option regimes will produce higher joint payoffs than the constrained second-order option regimes discussed in this article. To decouple the first- and second-order exercise prices, it would be necessary for a court to give the Resident the option of (a) being paid $\$ 50$ for permanently ceding to the Polluter the right to pollute or (b) paying $\$ 25$ to gain an injunction to permanently stop pollution. Ellickson proposed just such a scheme for resolving nuisance disputes in his seminal 1973 article. See Ellickson, supra note 4, at 748.

91. See Krier \& Schwab, supra note 4 , at 472 (" $[t]$ he judge calculates, exactly as the judge would in a rule two case, the $R s=$ damages if $P$ stays").

92. Levmore, supra note 6, at 2166-67. 
While this first-stage deterrence effect is perverse in Rule 5, it has a much more positive effect in the Rule 6 context. Under Rule 6, the second-stage put option is triggered by a first-stage taking. If Guido converts my watch to his possession, my common law put option of forcing Guido to pay me the permanent value of the watch may deter Guido from taking it in the first place. Or, in the nuisance context, Rule 6 might deter a Polluter from polluting to begin with. Under Rule 5, a Resident might regret bringing suit. Under Rule 6 , the analogous regret is a potential benefit: the Polluter may regret having polluted. Indeed, the genius of Rule 6 is that it can simultaneously deter initial takings and provide a safety net for occasions where the deterrence fails. If a taking happens by mistake, or because the deterrence fails, the put option can help make sure that the entitlement still flows to the higher-valuing user. Under Rule 6, setting damages at the taker's expected value will cause the initial entitlement holder to put the entitlement when, on average, it has a lower value. Thus, in the nuisance context, setting the Rule 6 damages equal to the Polluter's expected value of polluting can simultaneously deter Polluters from polluting, and, if pollution nonetheless occurs, it can help to assure that the higher valuer controls the pollution entitlement.

Thus, we can see two starkly different uses of put options. As described in Section I, put options, like traditional liability rules, can be used to facilitate the transfer of an entitlement when high transaction costs preclude traditional trade. But as described in Section II, put options can also be used as an additional means to implement property-rule protection of an initial entitlement-that is, to deter the non-consensual transfer of an entitlement. The crucial difference between deterring and facilitating puts is the size of damages, or in option terminology, the exercise price. A put exercise price set at the taker's expected value will tend to deter initial takings, ${ }^{93}$ while a put exercise price that is set lower-for example, at the court's estimate of what the parties would have contracted for if bargaining were possible-is likely to induce intentional taking. In the nuisance context, a "deterring" Rule 6 would set the potential damages equal to the Polluter's benefit from being able to continue polluting, while a "facilitating" Rule 6 would set a smaller damages amount equal to the amount that Polluter would have negotiated to pay the Resident for the right to pollute.

To get a handle on which type of put option regime is more appropriate, it is useful to consider the two dichotomies depicted in the following table.

93. However, even under this deterrence standard, potential takers with unexpected and undetectable high valuations may still be motivated to take in the shadow of such damages. 
Table 6. Factors Militating Toward Whether Put Options Should Deter or Facilitate Initial Taking

\begin{tabular}{|c|c|c|c|}
\cline { 3 - 4 } \multicolumn{2}{c|}{} & \multicolumn{2}{c|}{ Transaction Costs } \\
\cline { 2 - 4 } \multicolumn{2}{c|}{} & High & Low \\
\hline \multirow{2}{*}{$\begin{array}{l}\text { Initial } \\
\text { Taking }\end{array}$} & Deliberate & Facilitate & Deter?94 \\
\cline { 2 - 4 } & Mistaken & Deter & Deter \\
\hline
\end{tabular}

Table 6 focuses on the initial taker's mens rea (that is, whether the initial taking is deliberate or mistaken) and upon whether consensual trade is possible (that is, whether transaction costs are high or low).

When transaction costs are low, traditional theory suggests that we should set a "deterring" exercise price. Deterring non-consensual takings will tend to channel parties toward consensual transactions. ${ }^{95}$ Setting the Rule 6 damages to equal the judge's best estimate of the Polluter's valuation will not deter all takings, because Polluters with unexpectedly large valuations will still have an incentive to pollute. Richard Epstein has criticized awarding puts for mistaken takings, ${ }^{96}$ but setting the put's exercise price equal to the mistaken-maker's valuation will normally result in such low damages that the initial entitlement holder will not exercise the put, but instead will seek injunctive relief.

When high transaction costs preclude consensual trade, the put exercise price should be set to induce the efficient amount of non-consensual transfer. When the initial taking is non-deliberate, the court should focus solely on what exercise price will induce the aggrieved entitlement holder to put efficiently.

94. For a discussion of the question mark, see infra note 95.

95. But Eric Talley and $I$ have pointed out that when transaction costs are low, parties may also contract efficiently in the shadow of liability rules or other option regimes that tend to facilitate nonconsensual takings. See Ayres \& Talley, supra note 6, at 1058; Ayres \& Talley, supra note 33, at 238. If liability and property-rules regimes are equivalent when transaction costs are zero, there is no reason to think that property rules should suddenly dominate when the cost of transacting rises slightly.

96. See supra note 64. 
The "deterring" exercise price achieves this end. Under Rule 6, setting the damages equal to the Polluter's expected value of pollution will cause the Resident to put its no-pollution entitlement only when it values the entitlement less, on average, then the Polluter. This is simply a put application of KaplowShavell's proof that the optimal option exercise price should be set at the court's estimate of how much the non-option holder values the entitlement (and KrierSchwab's analysis of Rule 5 is in accord). ${ }^{97}$

The problem with the "deterring" Rule 6 exercise price in high transaction cost settings is that it may deter too many high-value Polluters from polluting initially and, thereby, triggering the Residents' put option. Under Rule 6, the "deterring" exercise price regime will cause the Polluter to either stop polluting or disgorge any expected benefit of polluting. While Polluter's with unexpectedly high values may nonetheless begin to pollute, a more efficient regime would encourage more initial takings. When transaction costs are high, efficiency-minded lawmakers will want to encourage a range of deliberate takings. This, of course, is the lesson of Boomer where the court allowed a Polluter to take the Resident's pollution right if the Polluter was willing to pay damages (which were substantially below the Polluter's value of polluting). ${ }^{98}$

But under Rule 6, the exercise price needs to tradeoff two different constraints to facilitate efficient non-consensual transfer: the Polluter's reluctance to pollute initially, and the Resident's reluctance to put its initial entitlement. When the initial taking is a deliberate act by the Polluter, Rule 6 creates a joint veto system where either party can stop the non-consensual transfer of the entitlement from the Resident to the Polluter. A "deterring" exercise price causes the Resident to efficiently put its entitlement (conditional on the Polluter's initial pollution), but also causes an inefficiently small amount of initial pollution. In the deliberate taking context, the optimal Rule 6 damages will be less than the "deterring" damages (set to equal the Polluter's value of pollution) and, instead, will approximately split the difference between the Resident's and the Polluter's mean valuations. ${ }^{99}$ Readers who think there is no earthly reason why the court should facilitate intentional takings of other people's property should remember that this is just the effect of the Boomer decision itself. Indeed, we are likely to have more intentional pollution under Rule 2 (with damages set at the Resident's expected value) than under Rule 6 (with facilitating damages set closer to the mean of the plaintiff's and defendant's mean valuation).

97. Kaplow \& Shavell, supra note 35, at 725; Krier \& Schwab, supra note 4, at 472.

98. Boomer v. Atlantic Cement Co., 257 N.E.2d 870 (N.Y. 1970).

99. Paul Goldbart and I are currently analyzing how courts should set optimal "facilitating" damages in a formal model. 
Thus, in Boomer, where the court estimated that the "total of permanent damages to all plaintiffs . . . was $\$ 185,000$ " but that enjoining the pollution might impose a cost on Atlantic Cement Co. closer to $\$ 45$ million, the deterring exercise price (of $\$ 45$ million) would be substantially in excess of a facilitating exercise price (at least half this amount). Instead of giving Atlantic Cement a Rule 2 call option to pollute if it paid the Resident's value, it would be both more equitable and efficient to give the residents an option to gain an injunction against pollution or an option to receive, say, $\$ 10$ or $\$ 20$ million as compensation for ceding a limited pollution right to Atlantic Cement. ${ }^{100}$

\section{Trespass, Nuisance, and the Costs of Determining Property Rights ${ }^{101}$}

The scope of a property owner's right to be unencumbered by nuisance is muddier than a property owner's right to be unencumbered by trespass or conversion. As Tom Merrill pointed out:

Intentional intrusions subject to the rule of trespass are governed by a standard of care which is "exceptionally simple and exceptionally rigorous." In order to establish an actionable trespass, all that A need show is that $B$ is responsible for an invasion of the column of space that defines A's possessory interest under the ad coelum rule. No weighing or balancing of costs and benefits is involved. . . .

Intentional harms subject to the law of nuisance, in contrast, are governed by a standard of care that is neither so simple nor so rigorous. . . . A will have to show . . . that the harm to $\mathrm{A}$ and similarly situated neighbors is greater than the benefits that accrue to $B$ and society generally from increased production and employment at the factory. ${ }^{102}$

100. The stylized facts of Boomer differ from the economic models of Section I (see also supra text accompanying note 74) because in Boomer there seems to have been little doubt that the plaintiffs' value was lower than the defendant's. Under such circumstances, there are a wide range of exercise prices-to wit any amount higher than the plaintiffs' highest possible valuation and lower than the defendant's lowest possible valuation-that will induce efficient ex post allocation of the entitlement (assuming still that bargaining is not possible). Within this range, the court has flexibility to do equity or promote ex ante investment incentives. It is only when the probability distributions of the litigants' valuation overlap-in the sense that there is some chance that defendants' valuation could be above or below the plaintiffs' valuation-that the court's choice of a more precise exercise price will affect ex post allocative efficience.

101. This section's title is taken from Thomas W. Merrill, Trespass, Nuisance, and the Costs of Determining Property Rights, 14 J. LEGAL STUD. 13 (1985).

102. Merrill, supra note 102 , at $16-18$. 
The law of nuisance is much more of a cost-benefit "standard"-turning on ex post judicial balancing-in comparison to the bright-line "rule" of trespass.

The examples of puts in the common law discussed in Section II are-like trespass rules-all triggered by clear invasion of plaintiffs' entitlements. When Rose steals my watch or builds an encroaching wall or becomes a holdover tenant, Rose usually knows at the time that she is unlawfully impairing my entitlement. In contrast, it is more difficult for Rose to know in advance whether her noise or dust emission will constitute a nuisance. ${ }^{103}$ It is reasonable to ask whether this "rule vs. standard" contrast might explain when the common law grants plaintiffs puts. In particular, there is a policy reason for granting remedial puts only when there are relatively bright-lined rules for what constitutes a taking. Rose qua Polluter may be less blameworthy because it is less clear when she acts that her emissions will subsequently be held to constitute a nuisance. Because of this uncertainty, it is reasonable to conclude that at least some polluters are acting with less intent. As an equitable matter, it is easier to justify giving the plaintiff a put option when the defendant has intentionally impaired the plaintiff's entitlement. The relative intentionality of the defendants' taking, however, cannot explain the common law's absolute refusal to grant plaintiffs a remedial put. First, some emissions are sufficiently noxious that defendants are constructively on notice that they will constitute a nuisance. Courts do not award plaintiffs remedial puts even when defendants intentionally create a nuisance. Second, courts give plaintiffs puts for even unintentional conversion. Finally, as argued above, ${ }^{104}$ even when the taking is unintentional, giving plaintiffs puts may give defendants appropriate incentives to avoid negligent takings.

A second and related potential ground for distinguishing nuisance from the common law puts in Section II concerns transaction costs. The common law tends to give puts in settings where the transaction costs are relatively low. It

103. The difficulty of identifying who owns what entitlements is part of what Carol Rose has

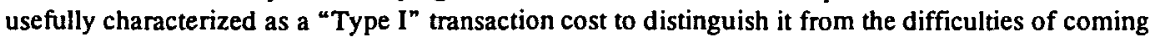
to terms once the bargainers and the subject matter have been identified (which Rose labels "Type II" transaction costs). See Rose, supra note 6, at 2189. Rose is right that not knowing who to bargain with is an important special species of transaction cost. But not knowing how much you own relative to another identified bargainer is not necessarily a transaction cost at all. Uncertainty about the relative legal rights and duties of two identified people can be thought of as a probabilistic division of the entitlement that can facilitate trade. Ayres \& Talley, supra note 6, at 1027; Jason Scott Johnston, Bargaining Under Rules Versus Standards, 11 J.L. ECON. \& ORG. 256 (1995).

Puts may also be more useful than calls in overcoming the "Type $I$ " transaction cost problem of not knowing who to bargain with. Although the government could legally exercise its eminent domain call option to buy, say automatic rifles from the public, a major obstacle to such a policy is finding out who owns the firearms. Buy-back programs that give the owners puts may be more successful. See supra note 47.

104. See supra note 64. 
is easier for the potential taker to bargain for a new watch than to bargain for the right to pollute. ${ }^{105}$ Courts might be more inclined as matter of equity to give plaintiffs a remedial put when defendant had an opportunity to buy the good on the open market but instead converted it. Under this theory, even a defendant's intentional takings may not warrant granting plaintiffs a remedial put if the defendant did not have a meaningful opportunity to bargain.

While this market avoidance theory is attractive, it does not provide a strong equitable basis for a court to favor giving the defendant a call (Rule 2) over giving the plaintiff a put. The plaintiff after all also does not have access to a market for the nuisance right in question. And by reducing the exercise price of the put (a la the "facilitating" approached discussed above), the court can still let allow the polluter to retain substantial benefits from polluting. When transaction costs are high, either puts or call help overcome the holdout problem. But the transaction costs themselves (or the degree of intentionality) provides little reason for letting the defendant instead of the plaintiff decide whether payment will be made. ${ }^{106}$

\section{CONCLUSION}

In a recent symposium honoring the twenty-fifth anniversary of One View of the Cathedral, it was pointed out that James Atwood had discussed the possibility of a Rule 4 in a Stanford Law Review Note published three years before Calabresi and Melamed's analysis. ${ }^{107}$ This revelation-graciously

105. Bargaining for nuisance rights may be difficult because of numerosity and because nuisance trading is more likely to involve geographically a bilateral monopoly. As argued supra note 103 , however, I believe it is mistaken to view the uncertainty over relative claims of the two parties as a transaction cost. Merrill has powerfully argued that the rules for determining what constitutes a nuisance are more standard-like because the costs of transacting are apt to be high. Merrill, supra note 102 , at 13.

106. The uncertainty over what constitutes a nuisance is caused in part because courts often ask whether "the gravity of the harm outweighs the utility of the actor's conduct." RESTATEMENT (SECOND) OF TORTS § 826(a) (1979). The plaintiff often has private information about the harm and the defendant often has private information about the benefits. Johnston, supra note 104 . The parties" valuation thus may affect not only the exercise price of put and call regimes but also affect whether the emissions are considered sufficiently severe to constitute an actionable nuisance. As Levmore has noted, having multiple legal consequences attend the litigants' report of value may create a "countervailing" effect that may, for example, discourage defendants from overstating the costs of an injunction. Levmore, supra note 6 , at 2170 . Stating a high factory value decreases the chance under the Restatement balancing test that the court will find the pollution to be a nuisance, but simultaneously increases the damages that the defendant would have to pay if a Rule 6 put is awarded to plaintiff (under either the deterring or facilitating approaches discussed above).

107. See James R. Atwood, Note, An Economic Analysis of Land Use Conflicts, 21 STAN. L. REV. 293, 315 (1969). 
acknowledged by Judge Calabresi ${ }^{108}$-highlights the difficulties of making claims of originality. Indeed, a major part of this Article is to suggest that, while put option regimes seem new and "startling" to the small cadre of scholars who have been writing in parallel on the subject, put options have been embedded in the common law for a long time without us noticing. Until now, most puts have been used to further the twin goals of deterring initial takings and, when deterrence fails, channeling the taken goods to the higher valuer. But we have suggested theoretical reasons why put option regimes with lower damages (i.e., exercise prices) might also play a valuable role in encouraging value-enhancing takings. Instead of giving Atlantic Cement the option of polluting and paying residents the damages of pollution, courts should consider giving residents the option of stopping the pollution or (if a majority or supermajority so votes) the option of ceding their "no pollution" entitlement in return for receiving an amount that the parties would have been willing to contract for (if transaction costs had not prevented consensual trade). ${ }^{109}$ It is perverse that Richard Epstein should be so against "put options" as a way to mitigate bilateral monopoly problems. Rule 6 shows that option regimes need not be part of a vast left-wing conspiracy to undermine property rights. Put options can shore up the property rights of the initial entitlement holder. Put options can deter takings, eliminate the risk that initial owners will be undercompensated, and, when takings do occur, help overcome the bilateral holdup problem. We could do a lot worse.

108. Guido Calabresi, Remarks: The Simple Virnues of the Cathedral, 106 YALE L.J. 2201, 2204 (1997).

109. In future work, I plan to argue that Atlantic Cement should be given the option to increase the potential damages that it would pay to help ensure that residents do not opt for injunctive relief merely as a bargaining ploy to extract more money from the Polluter. See Ayres \& Madison, supra note 69. 
Valparaiso University Law Review, Vol. 32, No. 3 [1998], Art. 1

https://scholar.valpo.edu/vulr/vol32/iss3/1 